IZA DP No. 7798

Intangible Knowledge Capital and Innovation in China

Belton M Fleisher

William H. McGuire

Adam Nicholas Smith

Mi Zhou

December 2013 


\title{
Intangible Knowledge Capital and Innovation in China
}

\author{
Belton M Fleisher \\ Ohio State University, CHLR and IZA \\ William H. McGuire \\ University of Washington Tacoma
}

Adam Nicholas Smith

Ohio State University

Mi Zhou

Agricultural Bank of China

Discussion Paper No. 7798
December 2013

IZA

P.O. Box 7240

53072 Bonn

Germany

Phone: +49-228-3894-0

Fax: +49-228-3894-180

E-mail: iza@iza.org

\begin{abstract}
Any opinions expressed here are those of the author(s) and not those of IZA. Research published in this series may include views on policy, but the institute itself takes no institutional policy positions. The IZA research network is committed to the IZA Guiding Principles of Research Integrity.

The Institute for the Study of Labor (IZA) in Bonn is a local and virtual international research center and a place of communication between science, politics and business. IZA is an independent nonprofit organization supported by Deutsche Post Foundation. The center is associated with the University of Bonn and offers a stimulating research environment through its international network, workshops and conferences, data service, project support, research visits and doctoral program. IZA engages in (i) original and internationally competitive research in all fields of labor economics, (ii) development of policy concepts, and (iii) dissemination of research results and concepts to the interested public.
\end{abstract}

IZA Discussion Papers often represent preliminary work and are circulated to encourage discussion. Citation of such a paper should account for its provisional character. A revised version may be available directly from the author. 
IZA Discussion Paper No. 7798

December 2013

\section{ABSTRACT}

\section{Intangible Knowledge Capital and Innovation in China}

Intangible knowledge capital (IKC) - technology produced by workers but not embodied in them - can offset the "middle income trap" as China exhausts the benefits of international technology transfer. IKC is productivity-enhancing among Chinese enterprises - more so in domestically owned than in foreign invested enterprises. Consistent with other research, we find that China's IKC generates patents in China, but fewer than in major industrialized economies. Among domestically owned enterprises, IKC growth has flowed more toward higher-tech, export-oriented industries, while among foreign invested enterprises, it has been oriented more toward domestic sales.

JEL Classification: O31, O33, O34, O43, P33

Keywords: intellectual capital, technology, economic growth, intellectual property, Asia, China

Corresponding author:

Belton M Fleisher

125 East 13th St

Unit 1204

Chicago, IL 60605

USA

E-mail: fleisher.1@osu.edu

\footnotetext{
* We gratefully acknowledge the University at Buffalo and the UB Center for Human Capital for their support of the conference at which this paper was originally presented. We are grateful for comments made by conference participants and by Seonghoon Kim, Zhiqiang Liu, Isaac Ehrlich and Joseph Kaboski on earlier versions of this paper.
} 


\section{INTRODUCTION.}

China’s spectacular economic growth in the post-Mao era has been generated by a high rate of saving; dramatic improvement in the efficiency of agriculture and industry; massive reallocation of labor from farming- to the non-farm- and from rural- to the urban sectors; and adopting and adapting modern technology. ${ }^{1}$ However, there are obvious limits to gains from resource reallocation and moving toward the world's technology frontier. Relying on these strategies alone, it is unclear whether China can safely negotiate the passage through "middle income" where many other countries become "trapped." 2

It is consistent with basic principles of growth theory that, in the absence of an unexpected discovery of a fountain of natural resources, China's future growth prospects depend on (1) accumulation of physical capital and traditional human capital (an educated workforce); (2) intangible knowledge capital; and (3) the continued institutional transformation necessary for innovation to have its full impact on productivity ${ }^{3}$. The analysis presented here will focus on (2), the accumulation of intangible knowledge capital (IKC). We view intangible knowledge capital as an intuitively appealing component of the intangible capital residual that eludes conventional wealth accounting efforts (Hamilton and Liu, 2013). Investments in physical- and traditional human- capital are both subject to diminishing returns, and institutional transformation is

\footnotetext{
${ }^{1}$ Representative literature documenting sources of China’s post-Mao growth include Chen, Huffman, and Rozelle, 2009; Hsieh and Klenow, 2009; Jin et al., 2010; Song, et al., 2011, not to mention the excellent analyses and summaries found in Naughton (2007 and earlier work).

${ }^{2}$ World Bank and Development Research Center of the State Council, 2012; Cai, 2012, Zhang et al., 2013.

${ }^{3}$ Kuo and Yang, 2008; Fleisher, Li, and Zhao, 2010; Coase and Wang, 2012.
} 
probably limited to the achievement of what can be shown to be "best practice". But investment in IKC is fundamental to innovation ${ }^{4}$ that can maintain growth (or avoid decline) of total factor productivity (TFP) and avoid convergence to what may well be a "middle income trap" for China. If all investments in IKC occurred within firms and generated no externalities, we could measure IKC as the difference between an enterprise's market value and the market value of its physical assets. However, investments in IKC can occur outside the firm (through government sponsored activities, for example), and returns to investments within a firm frequently benefit other firms, and are not necessarily confined to the same industry (Sveikaulkas, 2007; Hall and Jaffe, 2012). In the analysis that follows, we use broad industry groups as the basic unit of observation to mitigate, if not entirely eliminate, the difficulty of estimating impacts of investment in IKC that arise of failure to measure inter-firm spillovers.

We relate investments in IKC among Chinese manufacturing industries to three measures of economic performance. These include: (1) total factor productivity (TFP); (2) innovation as measured (imperfectly) by patent applications; and (3) China's comparative advantages as measured by the revealed comparative advantage (RCA) index. As previously discussed, the growth of TFP is essential if China is to avoid the middle income trap. Innovations, including those registered as patents, are an essential input into that TFP growth. Studying the relationship between IKC and the RCA index is, in part, a recognition that China's growth has not occurred

\footnotetext{
${ }^{4}$ Research and development (R\&D) expenditure is linked to innovation in an immense body of literature, and it is not necessary to cite specific examples. That R\&D capital is not itself subject to diminishing returns must rest on the untestable assumption that the number of potential inventions is unlimited.
} 
in a vacuum. If it is productive, the accumulation of IKC will affect not only Chinese firms, but also firms in the rest of the world, as China’s comparative advantage continues to evolve.

In the next section we overview the role of intangible knowledge capital in China's transition from a planned to a market economy. We discuss our data, present our methodology, and report our empirical results in the third section; the fourth section summarizes and concludes.

\section{KNOWLEDGE CAPITAL AND INSTITUTIONAL CHANGE IN TRANSITION.}

As Coase and Wang (2012) cogently note, China’s true “Great Leap Forward” began in the late 1970s; grass-roots “marginal revolutions” led the way forward, harnessing China's human capital in the development of new enterprises, markets, and a product mix that began to align with the country's comparative advantages based on its human and physical resource endowments (Lin, Cai, and Li, 1996). As Yue and Hua (2002) show, China’s surging exports resulted from its move toward its comparative advantage in labor-intensive production in its fastest-growing provinces. A natural outcome of this success has been the increasing scarcity of “cheap” labor and wage acceleration in coastal provinces, as discussed in recent special issues of China Economic Journal and China Economic Review (Huang and Cai, 2010; Ge and Yang, 2011; Fleisher et al., 2012). Two results of increasing relative scarcity of labor have been: (1) industries dependent on low-cost labor have tended to relocate inland--to areas where outmigration has not yet depleted the stock of low-skilled workers (Ge and Yang, 2011); (2) firms in high(er)-wage locations have shifted toward products and methods relying more heavily on skilled workers, physical capital, and intangible knowledge capital (United States NSF, 2010).

Investments in IKC to support continued transformation of the Chinese economy can come from the impact of the growing capacity of higher-education institutions in China $(\mathrm{Li}$, 
2010), from the flow of Chinese citizens returning after attending foreign colleges and universities (Ford, 2010), and from the local R\&D activities of domestic and foreign-invested enterprises (FIE) as well as from FIE transfers to their Chinese partners. Both international technology transfer and domestically-produced innovative activity are active in China (Fleisher, Li, and Zhao, 2010). ${ }^{5}$

The analysis presented here follows the work done by Hu, Jefferson, and Qian (2005) (henceforth HJQ) and Hu and Jefferson (2009). In these studies, the authors used firm-level data from the period 1995-2001 to show that R\&D investments made by domestic and foreign firms in China led to productivity growth and a greater propensity to patent. We extend their analysis by studying productivity and patent effects in China's post-WTO period (up to 2007), and also observing how similar investments in IKC have altered China’s comparative advantage.

\section{DATA, METHODOLOGY, AND EMPIRICAL RESULTS.}

Our data are industry aggregates reported in China’s Statistical Yearbook and Statistical Yearbook on Science and Technology. We measure IKC using data of industrial expenditures on Science and Technology (S\&T). China's National Bureau of Statistics broadly defines science and technology as "...activities closely related with the creation, development, dissemination and application of scientific and technical knowledge.” (NBS, 2008) This definition encompasses “...research and development (R\&D), the application of R\&D results, and related S\&T activities.” (NBS, 2008) This broad definition of S\&T is related to what

\footnotetext{
${ }^{5} \mathrm{Hu}$ and Jefferson (2003), in a study using data for the period 1996 through 2001 from the China State Intellectual Property Office (SIPO), show that a much larger proportion of patents obtained by foreign applicants are invention patents than is the proportion obtained by domestic applicants.
} 
McGratten and Prescott (2009) describe as "technology capital," the knowledge accumulated within firms engaged in research and development, among other activities. Following the literature (Hall, 2007), we measure the IKC stock as accumulated annual flows of S\&T expenditures depreciated at $15 \%$ per year ${ }^{6}$.

(a) Overview of IKC and Physical Capital.

[Table 1 here]

Table 1 presents our data for the S\&T stock and tangible physical capital stock among FIE's and domestically owned enterprises, by major industry group, for 1998 and 2007. Columns (2a), (4a), (6a), and (8a) show the ratio of the IKC stock to physical capital stock for FIE's and for domestic enterprises, respectively, in 1998 and 2007. The S\&T/physical capital ratio varies considerably across industries and is higher for enterprises without foreign involvement than for foreign-invested enterprises (FIE's). In most cases, the S\&T/physical capital ratio rose between 1997 and 2007. This is presented graphically in figure 1.

\section{[Figure 1 here]}

(i) Industry dispersion of the IKC/physical capital ratio over time.

The change in the S\&T/physical capital ratio between 1998 and 2007 for each industry group is depicted in figure 2. Both the levels of S\&T and physical capital increased substantially over the 1998-2007 period, but at about the same rates, so that the ratio of IKC to physical capital is only slightly higher in 2007 than in 1998 for both domestic and foreign-invested

\footnotetext{
${ }^{6}$ The initial stock is set as annual flow in 1998 multiplied by 5 . While the $15 \%$ depreciation rate is common in literature following the seminal papers of Griliches (1980 and earlier), it is not a measure that is robust to alternative and reasonable methods of estimating it (Hall, 2007), and estimation results based on the assumed 15\% depreciation rate should be evaluated accordingly.
} 
enterprises in the aggregate. However, the averages conceal substantial dispersion across industries. For example, for electrical machinery and equipment, the ratio of the stock of physical capital in 2007 to that in 1998 is 2.7 for FIE's and 2.3 for domestic enterprises, while the corresponding ratios for S\&T stock is approximately 3.4 for each ownership category. In contrast, for the electronic machinery and equipment industry, the FIE physical capital stock grew by over five-fold between 1998 and 2007, somewhat less than the 6-fold increase for domestically owned enterprises. But the S\&T stock grew by much more, both proportionately and in absolute magnitude, for FIEs than for domestically owned enterprises. Thus while the intangible-to-tangible capital stock ratio increased modestly for FIE's, it exhibits a sharp decline among domestic enterprises, as clearly illustrated in figure 2. This dramatic gap, which has emerged since the period studied by Hu, Jefferson, and Qian (2005), underlies our concern mentioned in the Introduction, that China's future growth prospects are linked to its providing an institutional framework within which domestic innovative activity will flourish.

[Figure 2 here]

(ii) Change over time in the share of FIEs in production and IKC stock.

Figures $3 \mathrm{a}$ and $3 \mathrm{~b}$ compare change over time in the share of FIEs in total industry production and change over time in the share of FIEs in total industry S\&T stock. We are interested to see if the influx of foreign direct investment into China has brought with it new emphasis on investing in IKC. The vertical axis measures the share of FIEs in total industry S\&T stock in the year 2001 divided by the share in 1998; the horizontal axis measures the share of FIEs in total industry production in the year 2001 divided by the share in 1998. Figure 3b shows the same variables, but the ratios are for the year 2007 divided by the year 2001. The figures therefore represent China's pre- and post-WTO trading regimes, respectively. Comparing figures 
3a and 3b we see wider dispersion in the growth of the FIE share in total S\&T stock across major industry groups (the y-axis dispersion of the plotted points). In the pre-WTO period, the scatter of FIE share in total S\&T change clusters around unity (excluding Petroleum and Fuels), while in the post-WTO period, the share of FIE's in total S\&T change varies between approximately 0.9 to almost 2.3 (for Textiles and Clothing). We take this change as evidence that foreign investors began to concentrate more on a specific sub-set of industries in China following WTO accession.

[Figure 3a here]

[Figure 3b here]

(iii) FIE versus domestic enterprise IKC growth.

Figures $4 \mathrm{a}$ and $4 \mathrm{~b}$ compare the growth of industry S\&T stock among FIE's with that of domestic enterprises. In figure 4a we see that the dispersion of S\&T stock growth (the 2001/1998 ratio) is somewhat smaller among FIE's (x-axis dispersion, (excluding the outlying Petroleum and Fuels)) than among domestic enterprises (y-axis dispersion). The standard deviation of the 2001/1998 ratio is 0.23 among FIEs (excluding Petroleum and Fuels) compared to 0.33 among domestic enterprises. Dispersion of the 2007/2001 ratio is greater than the 2001/1998 ratio for both ownership categories - 0.49 for FIEs and 0.42 for domestic enterprises, more than doubling for FIE's compared to slightly more than a 25\% increase for domestic enterprises. Moreover, the correlation between the cross-industry growth rates of FIEs and domestic enterprises is significantly negative in the post 2001 period compared to the clearly positive correlation over the pre-WTO period (negligible if Petroleum and Fuels is included). The negative correlation between FIE and domestic enterprise S\&T stock growth after 2001 reinforces the notion that some kind of sorting was taking place (as noted above in discussion of the increased dispersion of FIE shares in R\&D stock growth after 2001), with implications for the comparative 
advantages of domestic and foreign-invested enterprises. We infer a tendency for FIEs to focus on the domestic market while domestic enterprises appear to focus on exports. We explore this inference further in our more formal empirical work that follows.

[Figure 4a here]

[Figure 4b here]

\section{METHODOLOGY AND EMPIRICAL RESULTS.}

Our aim is to identify S\&T’s impact on indicators of innovation, productivity, and comparative advantage in China. These indicators are productivity as reflected in value added, holding constant conventional labor and capital inputs, patent applications ${ }^{7}$, and export performance as reflected in the (RCA) index (Balassa, 1965).

(a) Production and productivity.

Our approach to estimating the impact of IKC in China on productivity is to estimate the production function:

$$
Y_{(i, t)}=A_{(i, t)} L_{(i, t)}^{\alpha} K_{(i, t)}^{\beta} S \& T_{(i, t-1)}^{\theta} e^{u_{(i, t)}}
$$

where $Y_{(i, t)}$ represents industry value added, $L_{(i, t)}$ is the industry labor force, $K_{(i, t)}$ is the industry physical capital stock, measured as the net value of fixed assets, $S \& T_{i, t-1}$ is the stock of accumulated investments in S\&T, and the subscripts $i$ and $t$ denote industry and year,

${ }^{7}$ We note that patent applications are an imperfect measure of successful innovation, especially when lax and variable enforcement of IPR legislation can increase the likelihood that inventions are copied. A substantial body of research finds that patent protection has not seemed essential to the introduction of a significant number of innovations, and that the impact of patent protection on innovation and the number of patents varies widely across industries (Mansfield, Schwartz and Wagner, 1981, Levin, Klevorick, and Nelson, 1988, Arundel, 2001, Moser, 2005). 
respectively. Note that we employ lagged values of the S\&T stock on the right-hand side in order to address potential concerns over endogeneity with TFP in year $t$. As previously discussed, the S\&T stock is calculated as the depreciated sum of expenditures on science and technology (S\&T) by China’s large and medium enterprises, as recorded in China’s Statistical Yearbooks. In year $t$, the S\&T stock of a given industry is calculated as:

$$
S \& T_{(i, t)}=S \& T E x p e n d i t u r e s_{(i, t)}+0.85 * S \& T_{(i, t-1)}
$$

The S\&T stock for 1998, the first year in our sample, was calculated as five times the total S\&T expenditures in that year.

We assume the error term can be rewritten as:

$$
u_{i, t}=\gamma_{i} \delta_{t} \varepsilon_{i, t}
$$

where the $\gamma_{i}$ capture unobserved industry characteristics and $\delta_{t}$ captures unobserved characteristics of a given year, constant across all industries. The term $\varepsilon_{i, t}$ is an iid error term. Empirically, we estimate the production function in its log transformation:

$$
y_{(i, t)}=a_{(i, t)}+\alpha l_{(i, t)}+\beta k_{(i, t)}+\theta s \& t_{(i, t-1)}+\gamma_{i}+\delta_{t}+\varepsilon_{i, t}
$$

Because we are unable to exclude the possibility of a unit root in value added, we estimate (3) in its first difference form. ${ }^{8}$ The results are reported in Table 2.

[Table 2 here]

As a robustness check, we also estimate the production function using the estimation routine described in Levinson and Petrin (2003), hereafter L-P. These results are reported in Table $3 .^{\mathbf{9}}$

\footnotetext{
${ }^{8}$ We note that important differences may exist based upon firm ownership type (e.g. SOE vs. non-SOE). However, the aggregate LMEs data from which we draw our sample do not provide information on industry composition by registered ownership type. We leave such analysis for future work.
} 
[Table 3 here]

It is interesting to compare our production function estimation results with those of HJQ. Their study is based on the micro data for Large and Medium Enterprises that underlie our industry aggregates; their data cover the period 1995 through 1999, while ours encompass the period 1998 through 2007. HJQ's estimates are based on a very large sample of over 10,000 enterprises, while ours are based on the data aggregated into 29 industries. As do HJQ, we use time- and industry fixed effect estimation to estimate the effect of S\&T on TFP. HJQ also introduce a dummy variable for enterprise ownership (foreign or domestic). HJQ include an R\&D stock variables constructed similarly to our measurement of S\&T, but they also include measures of purchased technology (license fees to use patented technology and so on), which they also measure as a stock subject to depreciation. Their production elasticities for physical capital and labor are 0.46 and 0.54 , respectively, in OLS estimation that also includes terms for purchased technology and in-firm IKC. HJQ also report OLS estimates for domestic and foreign-invested enterprises separately. In HJQ's regressions for the FIE- and domestic enterprise samples, the estimated production elasticity for labor is lower than in the combined sample, approximately 0.10 for FIEs and 0.5 for domestic enterprises. In our first difference estimation (based on a sample including both foreign and domestically owned enterprises), the estimated production elasticity of labor is 0.45 or 0.46 , depending on the specification, and the output elasticity of capital is 0.57 .

Column 2 of Table 2 shows the estimated elasticity of value added with respect to total S\&T stock when using our first difference estimator. The point estimate is negative and

\footnotetext{
${ }^{9}$ We also estimated the production function in per worker form. The results were nearly identical to those presented in Table 2, so they are not presented here.
} 
marginally significant. This may reflect short term losses due to "expensing" investments in S\&T. ${ }^{10}$ Column 3 shows comparable estimation results when the total S\&T stock is divided into the stocks of domestic firms and FIEs. These results do not show any significant relationship between S\&T and industry value added. Column 4 introduces a "spillover" term, calculated as the sum of S\&T stocks for all industries except the industry of observation. The results in column 4 indicate no relationship between S\&T spillovers and industry value added.

In order to address concerns over endogeneity bias in the estimation of production function parameters, we also estimated each specification in Table 2 using the Levinson Petrin (L-P) estimator. These results are presented in Table 3. In column 2, the estimated coefficient on total S\&T stocks is positive but insignificant. In column 3, we can see that domestic S\&T stocks are positively related to value-added, and the relationship is significant at the $10 \%$ level. No significant relationship is detected between value added and foreign S\&T stocks. In column 4, the estimated coefficient on the S\&T spillover variable suggests substantial, positive interindustry spillover effects from investments in S\&T. We also observe a significant positive relationship between domestic S\&T stocks and value added. This specification also shows a negative relationship between foreign S\&T stocks and value added, which is significant at the $10 \%$ level.

In their production function estimates, HJQ report positive, significant estimated elasticities for R\&D stock (not differentiated by ownership), a positive, significant elasticity for technology stock purchased from foreign enterprises and a negative, significant elasticity for technology stock purchased from domestic enterprises. Methodological differences make it

\footnotetext{
${ }^{10}$ The estimated coefficient on S\&T stocks becomes positive and significant at the $10 \%$ level when lags are increased from one to two periods.
} 
difficult to directly compare our point estimates to theirs, but their estimated elasticity of valueadded with respect to R\&D stock ranges between 0.005 and 0.029 in pooled samples. By comparison, our estimated elasticity on domestic S\&T stocks ranges from 0.31 to 0.32 using the L-P estimator. This could imply that production in China has become more S\&T-intensive since the period studied by HJQ, or it may indicate the presence of substantial intra-industry spillovers from investment in S\&T, which were not studied in HJQ.

(b) Patent applications.

Our approach to patent applications follows that of HJQ (2005), in that we estimate parameters of a "patent production function" in which an input is S\&T. It has been shown that patent applications are filed according to a Poisson process, which describes the number of occurrences of an event in a given time interval (Hausman et al. 1984). For patent data measured in panels, there is a further issue concerning over-dispersion, whereby the conditional variance exceeds the conditional mean (Hausman et al. 1984; Cincer 1997). Thus, we use a negative binomial model to estimate the following patent production function with year- and industry fixed effects:

$$
\operatorname{Applications}_{(i, t)}=f\left(s \& t_{(i, t-1)}, l_{(i, t-1)}\right)
$$

where S\&T is as defined previously, and $l$ is included to capture scale effects that may be important in explaining the propensity to patent in an industry (Hu and Jefferson, 2009).

Estimation results for the patent application model are presented in Table 4. Once again, our data are industry aggregates of the firm-level data for Large and Medium Enterprises (LME's) and cover the period 2001 through 2007, compared to the period 1995 through 2001 in the samples used in HJQ (2005) and Hu and Jefferson (2009).

[Table 4 here] 
We emphasize the results for domestic invention patent applications. Our regressors are similar to those of Hu and Jefferson (2009), except that we do not include a quadratic term for S\&T expenditures. We also add the lagged value of domestic invention patents to address potential problems of autocorrelation. Despite the differences in time period covered and in specification, our estimation results appear to tell a story quite similar to that of Hu and Jefferson (2009). Column 1 shows that total S\&T stocks are positively associated with the rate at which domestic firms in an industry file for patents. Specifically, an industry experiencing a $1 \%$ increase in total S\&T stock will approximately double the rate at which domestic firms file patent applications. Column 2 shows the results when total S\&T stock is divided between domestic enterprises and FIEs. These results indicate that a $1 \%$ increase in domestic S\&T stocks will increase the rate at which domestic firms file for patents by a factor of 1.9. There appears to be no relationship with FIE S\&T stocks and domestic patent filings. The negligible impact of FIE S\&T activity on patent applications is not surprising, given our focus on domestic patent applications, but in contrast to Hu and Jefferson (2009), we find no evidence of intra-industry spillovers from FIEs to domestic enterprises. Hu and Jefferson infer a "demonstration effect" from their observation that the share of FIE's in total industry value added increases the propensity of domestic enterprises to apply for patents. Column 3 reports results when we include inter-industry S\&T spillovers. Once again, we see strong positive spillover effects from S\&T investments in other industries. A 1\% increase in S\&T stock among other industries will increase the rate of patent applications by domestic firms by a factor of 1.6 , compared to 2.3 for domestic S\&T stocks in the same specification.

(c) IKC and exports. 
Finally, we examine the relationship between investment in S\&T and China's export performance, as reflected in revealed comparative advantage (RCA). RCA is a measure of the share of a Chinese industry's exports in the nation's total exports relative to the corresponding measure for total world exports. The RCA index for industry $i$ in country $c$ vs the rest of the world $w$ is:

$$
R C A_{i}=\frac{X_{i, C} / X_{C}}{X_{i, W} / X_{W}}
$$

An RCA index greater than 1 indicates that country $C$ has a comparative advantage in good $i$. This implies that the industry's share of total exports from $C$ to the rest of the world exceeds the industry's share in total world exports. Figures $5 \mathrm{a}$ and $5 \mathrm{~b}$ illustrate the relationship between the change in S\&T stock and the change in RCA index by industry over our sample period. Figure 5a displays this relationship for domestic enterprises while Figure 5b represents FIEs. The figures illustrate an interesting contrast between domestic and FIE enterprises. For textiles and clothing, domestic industries display a substantial decline in S\&T stock between 2001 and 2007, while FIEs increased their S\&T stocks over four-fold. At the same time, China's RCA in textiles and clothing plummeted by almost one-half. In contrast, China's RCA nearly doubled in the electrical machinery and the electronic and communication equipment industries, and its S\&T stock more than tripled in the 2001-2007 period. A simple trend line suggests that domestic enterprises' S\&T expenditures were aimed toward industries in which China was increasing its relative share of world exports, while FIE investments in S\&T have been associated with a stronger focus on the domestic (Chinese) market. However, this trend in domestic industries may be driven by a small number of outlier firms. We turn to more rigorous empirical analysis to address this concern.

[Figure 5a here] 


\section{[Figure 5b here]}

To more formally explore the relationship between S\&T and an industry's RCA index, we estimate the following model:

$$
R C A_{(i, t)}=f\left(s \& t_{(i, t-1)}\right)
$$

where variables are as defined above and the period covered is 2001 to 2007. Estimation results are presented in Table 5. As with (3), the model in (6) is estimated in first-difference form. Column 1 presents estimation results using total industry S\&T stocks. While the point estimate is positive, the estimated relationship is not significant. In column 2, S\&T stock is divided into its domestic and FIE components. The results indicate that a 1\% increase in domestic S\&T stock will raise the industry RCA index by 0.04 points. This effect is small (about $4 \%$ evaluated at the mean), and would be sufficient to move an industry from the $50^{\text {th }}$ to the $53^{\text {rd }}$ percentile of the distribution. The point estimate on FIE S\&T is negative, and implies a decrease in the RCA index of approximately $2 \%$ given a $1 \%$ increase in FIE S\&T stocks. This is consistent with the pattern observed in Figures 5a and 5b. Domestic investments in IKC have been associated with increased competitiveness in world markets, while FIE investments in IKC have been more oriented toward domestic competitiveness. Column 4 presents the results incorporating spillovers from S\&T stocks in other industries. The estimated coefficient on domestic S\&T stock is of similar sign, significance and magnitude. The estimated coefficient on FIE S\&T stocks is negative, but not significant at the $10 \%$ level. The relationship with S\&T spillovers is negative and of similar in magnitude to the effect observed from domestic S\&T.

[Table 5 here]

\section{SUMMARY AND CONCLUSIONS.}


We define intangible knowledge capital as knowledge produced by employees and standalone innovators that is transferrable across individuals and firms. We measure IKC as the depreciated stock of expenditures on science and technology. Our estimation results provide evidence that domestic IKC has led to increases in productivity following China's WTO accession. While there is some evidence that FIE investments in IKC reduce productivity, this estimate is not robust across model specifications. Domestic investments in IKC also lead to increases in patented technology among domestic firms, while the "demonstration effect" of foreign IKC noted by Hu and Jefferson (2009) seems to be absent. Interestingly, we find that the IKC of domestically-owned enterprises in China appears to support a movement toward expanding exports, while that of FIEs has gravitated toward industries producing for the domestic market. This suggests a change in China's comparative advantage in favor of technology-intensive industry. Exploring the implications of these trends for China and the rest of the world should provide direction for interesting further research.

Our results are based on data of large and medium enterprises aggregated by industry, covering the period from 1998 through 2007. They are broadly consistent with results reported by Hu, Jefferson, and Qian (2005) and by Hu and Jefferson (2009) whose work relies on micro data of large and medium enterprises through 2001. Using industry aggregates allows us to capture important intra- and inter-industry spillovers, which were not identified in this previous work.

As Hamilton and Liu (2013) suggest, intangible wealth is an important and elusive component of the total capital of the world's higher-income countries. The growth of the IKC stock of both domestically owned and foreign-invested enterprises in China has increased sharply since China joined in TRIPS protection of intellectual capital and entered WTO. The 
positive returns seen to investments in IKC in this study suggest that to avoid middle-income stagnation, China should emphasize the development of an institutional and legal framework that assures both adequate protection for innovators, as well as encouragement of spread of domestically produced new technology. 
References

Amsden, A., Tschang, T., Goto, A. (2001). Do Foreign Companies Conduct R\&D in Developing Countries? Asian Development Bank Working Paper (14). Tokyo.

Arundel, A. (2001). The Relative Effectiveness of Patents and Secrecy for Appropriation. Research Policy (30), 611-24.

Balassa, B. (1965). Trade Liberalization and “Revealed” Comparative Advantage. Manchester School (33), 99-123.

Cai, F., (2012). Is There a “Middle-income Trap?” Theories, Experiences, and Relevance to China. China \& World Economy (20), 49-61.

Chen, Z., Huffman, W. E., Rozelle, S. (2009). China Economic Review (20), 153-161.

China National Bureau of Statistics. (1998-2008) China Statistical Yearbook on Science and Technology. Beijing: China Statistical Publishing House.

Coase, R., Wang, N. (2012). How China Made Its Great Leap Forward. Wall Street Journal April 15 p. A15.

Dobson, W., Safarian, A. E., (2008). The Transition from Imitation to Innovation: An Enquiry into China’s Evolving Institutions and Firm Capabilities. Journal of Asian Economics (19), 301-311.

Fleisher, B., Fearn, R., and Ye, Z. (Eds.) (2011). Special Issue: Has China Passed the Lewis Turning Point? China Economic Review (22), 535-626.

Fleisher, B., Li, H., Zhao, M. (2010). Human Capital, Economic Growth, and Regional Inequality in China. Journal of Development Economics (92), 215-231. 
Ford, P. (2010). China’s Promise Lures Grads Home. Christian Science Monitor, December 2. [http://www.csmonitor.com/World/Asia-South-Central/2010/1202/China-s-promiselures-grads-home]. Last Accessed: September 27 ${ }^{\text {th }}, 2013$.

Fraumeni, B., Okubo, S., (2005). R\&D in the National Income and Product Accounts: A First Look at its Effect on GNP., pp. 275-316 in Corrado, C. Corrado, J. Haltiwanger, \& D. Sichel (Eds.), Measuring Capital in the New Economy, (pp. 275-316). Chicago, US: University of Chicago Press

Griliches, Z. (1980). Returns to Research and Development Expenditures in the Private Sector, in J. W. Kendrick \& B. Vaccara, (Eds), New Developments in Productivity Measurement (pp. 419-454). Chicago, US: University of Chicago Press.

Hall, B. H., 2007. Measuring the Returns to R\&D: The Depreciation Problem. NBER Working Paper 13473. [http://www.nber.org/papers/w13473]. Last Accessed: September $27^{\text {th }}$, 2013.

Hall, B. H., Jaffe, A. B. (2012). Measuring Science, Tehcnology, and Innovation: A Review. Report prepared for the Panel on Development Science, Technology, and Innovation Indicators for the Future, National Academies of Science. [http://people.brandeis.edu/ ajaffe/Hall-Jaffe\%20HJ12_indicators_final.pdf]. Last Accessed: September $27^{\text {th }}, 2013$.

Hamilton, K., Liu, G., (2013). Human Capital, Tangible Wealth, and the Intangible Capital Residual. Policy Research Working Paper 6391. Washington, D.C., The World Bank. [http://econ.worldbank.org/external/default/main?pagePK=64165259\&piPK=64165421\& theSitePK=469372\&menuPK=64166093\&entityID=000158349_20130326131617\&cid= DEC_PolicyResearchEN_D_INT]. Last Accessed: September 27 $7^{\text {th }}, 2013$. 
Hsieh, C.T., Klenow, P. J. (2007). Misallocation and Manufacturing TFP. Quarterly Journal of Economics (124), 1403-48.

Huang, Y., Cai, F. (2010). (Eds), Special Issue: Debating the Lewis Turning Point in China. China Economic Journal (3), 107-220.

Hu, A. G., Jefferson, G. H. (2003). Returns to Research and Development in Chinese Industry: Evidence from State-Owned Enterprises in Beijing. China Economic Review (15), 86107. , (2009). A Great Wall of Patents: What is Behind China’s Recent Patent Explosion? Journal of Development Economics (90), 57-58. Hu, A. G., Jefferson, G. H., \& Qian, J. (2005). R\&D and Technology Transfer: Firm-Level Evidence From Chinese Industry. Review of Economics and Statistics (87), 780-786. Keller, W. (2002). Geographic Localization of International Technology Diffusion. American Economic Review (90), 120-42. 2009. International Trade, Foreign Direct Investment, and Technology Spillovers. NBER Working paper 15441. [http://www.nber.org/papers/w15442]. Last Accessed: September 27 ${ }^{\text {th }}, 2013$.

Kuo, C. C., Yang, C. H., (2008). Knowledge Capital and Spillover on Regional Economic Growth: Evidence from China. China Economic Review (19), 594-604.

Levin, R. C., Klevorick, A. K., Nelson, R. R., 1988. Appropriating the Returns from Industrial R\&D. Cowles Foundation Discussion Papers: 1052. Cowles Foundation, Yale University.

Levinson, J. and Petrin, A. 2003. Estimating Production Functions Using Inputs to Control for Unobservables. Review of Economics and Statistics (70). 317-342. 
Li, H. (2010). Higher Education in China—Complement or Competition to US Universities? In Charles T. C. (ed.), American Universities in Global Competition. Chicago, US: University of Chicago Press, 269-304.

Lin, J., Cai, F., Li, Z., (1996). The China Miracle: Development Strategy and Economic Reform. Hong Kong, China: China University Press.

Mansfield, Edwin, Scwartz, Mark, Wagner, Samuel, (1981). Imitation Costs and Patents: an Empirical Study. Economic Journal, (91). 907-18.

McGrattan, E. R., Prescott, E. C. (2009). Openness, technology capital, and development. Journal of Economic Theory (144), 2454-2476.

Moser, Petra, (2005). How Do Patent Laws Influence Innovation? Evidence from NineteenthCentury World Fairs. American Economic Review (95), 1214-1236.

Naughton, B., (2007). The Chinese Economy. Cambridge, MA: The MIT Press.

Nelson, R., (1964). Aggregate production functions and Medium-Range Growth Projections. American Economic Review (54), 575-605.

Nelson, R. R. (1988). Modeling the Connections in the Cross Section between Technical Progress and R\&D Intensity. Rand Journal of Economics, (19), 416-436.

Nin-Pratt, A., Yu, B., Fang, S., (2010). Comparisons of Agricultural Productivity Growth in China and India. Journal of Productivity Analysis, (33), 209-223.

Ögütçü, M. (2002). Foreign Direct investment and Importance of the "Go West” Strategy in China’s Energy Sector. [http://www.oecd.org/dataoecd/1/35/2085596.pdf]. Last Accessed: September $27^{\text {th }}, 2013$.

Song, Z., Storesletten, K., Zilibotti, F. (2011). Growing Like China. American Economic Review, (101), 196-233. 
Sveikauskas, L. (2007). R\&D and Productivity Growth: A Review of the Literature. BLS Working Papers \#408. Washington, D.C.

United States National Science Foundation (NSF) (2010). Science and Engineering Indicators 2010. [http://www.nsf.gov/statistics/seind10/c0/c0s11.htm]. Last Accessed: September $27^{\text {th }}, 2013$.

Wolff, E. N. (1991). Capital Formation and Productivity Convergence Over the Long Term. American Economic Review (81), 565-379.

World Bank and Development Research Center of the State Council, the People's Republic of China. China 2030: Building a Modern, Harmonious, and Creative High-income Society. Washington, D. C.: IBRD/International Development Association of The World Bank.

Wu, K., Jiang, R., Cai, H., Jefferson, G. H., 2013. Trade and Intellectual Property Rights as Channels for Economic Growth. Asia Pacific Journal of Accounting and Economics (20), 20-36.

Yue, C., Hua, P. (2002). Does Comparative Advantage Explain Export Patterns in China? China Economic Review (13), 276-296.

Zhang, G., Chen, X. (2012). The Value of invention Patents in China: Country Origin and Technology Field Differences. China Economic Review (23), 357-370.

Zhang, L., Pollak, E., Darwin, R., Boswell, M., Rozelle, S. (2013). Are Elite University Graduates Aiding China’s Transition to an Innovation-based Economy? Results from a Career Choices Survey among Would-be Innovators in China and the United States. Asia Pacific Journal of Accounting and Economics (20), 58-69. 


\section{Tables}

Table 1

Capital Stock and S\&T Stock (100,000,000 yuan at 1990 prices)

\begin{tabular}{|c|c|c|c|c|c|c|c|c|c|c|c|c|}
\hline & (1) & (2) & $(2 a)$ & (3) & (4) & (4a) & (5) & (6) & (6a) & (7) & (8) & (8a) \\
\hline & $\begin{array}{c}\text { FIE } \\
\text { Capital } \\
\text { Stock }\end{array}$ & $\begin{array}{l}\text { FIE } \\
\text { S\&T } \\
\text { Stock }\end{array}$ & $\begin{array}{l}\text { Ratio } \\
1998\end{array}$ & $\begin{array}{c}\text { FIE } \\
\text { Capital } \\
\text { Stock }\end{array}$ & $\begin{array}{l}\text { FIE } \\
\text { S\&T } \\
\text { Stock }\end{array}$ & $\begin{array}{l}\text { Ratio } \\
2008\end{array}$ & $\begin{array}{c}\text { Domestic } \\
\text { Capital } \\
\text { Stock }\end{array}$ & $\begin{array}{c}\text { Domestic } \\
\text { S\&T } \\
\text { Stock }\end{array}$ & $\begin{array}{l}\text { Ratio } \\
1998\end{array}$ & $\begin{array}{c}\text { Domestic } \\
\text { Capital } \\
\text { Stock }\end{array}$ & $\begin{array}{c}\text { Domestic } \\
\text { S\&T } \\
\text { Stock }\end{array}$ & $\begin{array}{l}\text { Ratio } \\
2007\end{array}$ \\
\hline Industries & 1998 & 1998 & 0.02 & 2007 & 2007 & 0.05 & 1998 & 1998 & 0.06 & 2007 & 2007 & 0.11 \\
\hline Food and Tobacco & 456.35 & 8.44 & 0.03 & 870.05 & 43.01 & 0.04 & 1094.62 & 68.86 & 0.14 & 1707.03 & 186.21 & 0.09 \\
\hline Textiles,Clothing,Etc. & 410.71 & 11.79 & 0.03 & 984.67 & 42.25 & 0.04 & 806.02 & 110.09 & 0.15 & 1689.34 & 160.23 & 0.05 \\
\hline $\begin{array}{l}\text { Timber, } \\
\text { Furniture }\end{array}$ & 193.95 & 5.52 & 0.03 & 740.88 & 33.26 & 0.05 & 229.77 & 33.78 & 0.07 & 1095.69 & 58.60 & 0.06 \\
\hline $\begin{array}{l}\text { Printing and } \\
\text { Recorded Media }\end{array}$ & 90.53 & 2.63 & 0.01 & 213.61 & 9.96 & 0.02 & 109.02 & 7.61 & 0.05 & 244.15 & 15.23 & 0.05 \\
\hline $\begin{array}{l}\text { Petroleum and other } \\
\text { Fuels }\end{array}$ & 36.40 & 0.28 & 0.06 & 256.97 & 5.90 & 0.04 & 856.76 & 43.19 & 0.14 & 1447.18 & 75.91 & 0.15 \\
\hline $\begin{array}{l}\text { Chemical Raw } \\
\text { Materials and } \\
\text { Products }\end{array}$ & 242.52 & 15.62 & 0.14 & $1,117.19$ & 49.13 & 0.20 & 1290.98 & 178.73 & 0.19 & 2511.83 & 378.01 & 0.23 \\
\hline Pharmaceuticals & 69.51 & 9.64 & 0.06 & 213.10 & 42.65 & 0.07 & 199.39 & 37.72 & 0.10 & 544.41 & 126.11 & 0.12 \\
\hline $\begin{array}{l}\text { Chemical Fibers, } \\
\text { Rubber, Plastic }\end{array}$ & 384.14 & 21.70 & 0.07 & 816.78 & 57.70 & 0.06 & 663.43 & 63.24 & 0.09 & 1125.21 & 139.89 & 0.12 \\
\hline $\begin{array}{l}\text { Mineral, Ferrous, } \\
\text { Nonferrous } \\
\text { Materials }\end{array}$ & 604.63 & 44.13 & 0.20 & $1,740.02$ & 98.16 & 0.18 & 2927.43 & 269.44 & 0.32 & 7470.11 & 870.64 & 0.30 \\
\hline $\begin{array}{l}\text { General Purpose } \\
\text { Machinery }\end{array}$ & 490.52 & 97.30 & 0.15 & $1,953.01$ & 348.29 & 0.20 & 1712.97 & 545.73 & 0.27 & 3452.66 & 1022.84 & 0.41 \\
\hline $\begin{array}{l}\text { Electrical Machinery, } \\
\text { Equipment }\end{array}$ & 217.22 & 33.56 & 0.20 & 594.99 & 118.22 & 0.22 & 404.72 & 109.00 & 0.30 & 916.71 & 379.50 & 0.18 \\
\hline $\begin{array}{l}\text { Electronic } \\
\text { Machinery, Equipmt. }\end{array}$ & 431.55 & 86.92 & 0.02 & $2,338.46$ & 511.87 & 0.05 & 424.99 & 128.56 & 0.06 & 2533.71 & 455.79 & 0.11 \\
\hline
\end{tabular}


Table 2

Production Function Estimates: Two-Way Fixed Effects

\begin{tabular}{lcccc}
\hline & $(1)$ & $(2)$ & $(3)$ & $(4)$ \\
Two-Way Fixed Effects & Log VA & Log VA & Log VA & Log VA \\
\hline & $0.46^{* * *}$ & $0.45^{* * *}$ & $0.45^{* * *}$ & $0.45^{* * *}$ \\
Log Labor & $(0.00)$ & $(0.00)$ & $(0.00)$ & $(0.00)$ \\
& $0.57^{* * *}$ & $0.57^{* * *}$ & $0.57^{* * *}$ & $0.57^{* * *}$ \\
Log K & $(0.00)$ & $(0.00)$ & $(0.00)$ & $(0.00)$ \\
& & & -0.12 & -0.12 \\
Log Domestic S\&T Stock (t-1) & & & $(0.23)$ & $(0.23)$ \\
& & & -0.04 & -0.04 \\
Log FIE S\&T Stock (t-1) & & $-0.19 *$ & $(0.16)$ & $(0.16)$ \\
& & $(0.09)$ & & \\
Log Total S\&T Stock (t-1) & & & & 0.00 \\
& & & & $(1.00)$ \\
Log S\&T Spillover (t-1) & & & & \\
& 141 & 141 & 141 & 141 \\
Observations & 0.80 & 0.81 & 0.81 & 0.81 \\
R-squared & YES & YES & YES & YES \\
Industry FE & YES & YES & YES & YES \\
Year FE & & & & \\
\hline
\end{tabular}

Notes: Data for the models in columns (1)-(5) are aggregated from the LMEs sample for 2001-2007, excluding 2004 for missing data.

The number of industries included in the sample is 29.

Data on S\&T expenditures taken from recorded total expenditures on Science and Technology by large and medium enterprises in China's Statistical Yearbook.

S\&T stock in 1998 was calculated as five times the flow in that year. S\&T stock in subsequent years is calculated by adding the flow in year $t$ to the stock in year $t-1$, discounted at $15 \%$.

Values in parentheses are p-values calculated using standard errors estimated with a jackknife procedure

Significance levels $* * *, * *$, and $*$ are $\mathrm{p}<0.01,0.05$, and 0.1 , respectively.

S\&T Spillover is the sum of S\&T stocks from all other industries

Weighted S\&T Spillover weights S\&T stocks from all other industries using input-output coefficients 
Table 3

Production Function Estimates: Levinson-Petrin

\begin{tabular}{lcccc}
\hline Levinson-Petrin & $(1)$ & $(2)$ & $(3)$ & $(4)$ \\
& Log VA & Log VA & Log VA & Log VA \\
\hline Log Labor & 0.22 & 0.23 & $0.47^{* * *}$ & $0.49^{* * *}$ \\
& $(0.26)$ & $(0.21)$ & $(0.00)$ & $(0.00)$ \\
Log K & 0.33 & 0.20 & 0.38 & 0.09 \\
& $(0.37)$ & $(0.65)$ & $(0.15)$ & $(0.74)$ \\
Log Domestic S\&T Stock (t-1) & & & $0.31^{*}$ & $0.32^{* *}$ \\
& & & $(0.07)$ & $(0.03)$ \\
Log FIE S\&T Stock (t-1) & & & -0.23 & $-0.25^{*}$ \\
& & 0.09 & $(0.15)$ & $(0.05)$ \\
Log Total S\&T Stock (t-1) & & $(0.50)$ & & \\
Log S\&T Spillover (t-1) & & & & $0.50 * * *$ \\
& & & & $(0.00)$ \\
Observations & 145 & 145 & 145 & 145 \\
\hline
\end{tabular}

Notes: Data for the models in columns (1) - (5) are industry aggregates for the years $2003-2007$

The number of industries included in the sample is 29.

Data on S\&T expenditures taken from recorded total expenditures on Science and Technology by large and medium enterprises in China's Statistical Yearbook.

S\&T stock in 1998 was calculated as five times the flow in that year. S\&T stock in subsequent years is calculated by adding the flow in year $t$ to the stock in year $t-1$, discounted at $15 \%$.

Values in parentheses are p-values

Significance levels $* * *, * *$, and $*$ are $\mathrm{p}<0.01,0.05$, and 0.1 , respectively

S\&T Spillover is the sum of S\&T stocks from all other industries 
Table 4

Domestic Invention Patents

\begin{tabular}{lccc}
\hline & $\begin{array}{c}(1) \\
\text { Domestic } \\
\text { Invention } \\
\text { Patents }\end{array}$ & $\begin{array}{c}(2) \\
\text { Domestic } \\
\text { Invention } \\
\text { Patents }\end{array}$ & $\begin{array}{c}(3) \\
\text { Domestic } \\
\text { Invention } \\
\text { Patents }\end{array}$ \\
\hline Domestic Invention Patents (t-1) & 1.00 & 1.00 & 1.00 \\
Log Labor & $(0.81)$ & $(0.79)$ & $(0.72)$ \\
Log Domestic S\&T Stock (t-1) & 1.36 & 1.38 & 1.23 \\
& $(0.12)$ & $(0.14)$ & $(0.36)$ \\
Log FIE S\&T Stock (t-1) & & $1.89 * *$ & $2.26^{* * *}$ \\
& & $(0.01)$ & $(0.00)$ \\
Log Total S\&T Stock (t-1) & & 0.95 & 0.90 \\
Log S\&T Spillover (t-1) & $2.02 * * *$ & $(0.85)$ & $(0.62)$ \\
& $(0.00)$ & & $1.61 *$ \\
Observations & & & $(0.06)$ \\
Industry FE & & & 143 \\
Year FE & 143 & 143 & YES \\
\hline
\end{tabular}

Notes: Data on S\&T expenditures taken from recorded total expenditures on Science and Technology by large and medium enterprises in China's Statistical Yearbook.

S\&T stock in 1998 was calculated as five times the flow in that year. S\&T stock in subsequent years is calculated by adding the flow in year $t$ to the stock in year $t-1$, discounted at $15 \%$.

The models estimated above cover the years 2001 to 2007, excluding 2004.

Estimates reported above represent incidence rate ratios

Values in parentheses are p-values calculated using standard errors estimated with a jackknife procedure

Significance levels $* * *, * *$, and $*$ are $\mathrm{p}<0.01,0.05$, and 0.1 , respectively.

S\&T Spillover is the sum of S\&T stocks from all other industries.

Weighted S\&T Spillover weights S\&T stocks from all other industries using input-output coefficients 
Table 5

RCA Model Results

\begin{tabular}{lccc}
\hline VARIABLES & $(1)$ & $(2)$ & $(3)$ \\
& RCA & RCA & RCA \\
Domestic S\&T Stock (t-1) & & & \\
& & $0.04^{* * *}$ & $0.04^{* * *}$ \\
FIE S\&T Stock (t-1) & & $-0.00)$ & $(0.00)$ \\
& & $(0.06)$ & -0.01 \\
Total S\&T Stock (t-1) & 0.02 & & $(0.42)$ \\
& $(0.37)$ & & \\
S\&T Spillover (t-1) & & & $-0.04^{* *}$ \\
& & & $(0.05)$ \\
S\&T Spillover (t-1, weighted) & & & \\
& & & \\
Observations & 78 & 78 & 78 \\
R-squared & 0.06 & 0.09 & 0.11 \\
Industry FE & YES & YES & YES \\
Year FE & YES & YES & YES \\
\hline
\end{tabular}

Notes: Data for the models in columns (1)-(5) are aggregated from the LMES sample for 2001-2007, excluding 2004 for missing data.

The number of industries included in the sample is 26.

Data on S\&T expenditures taken from recorded total expenditures on Science and Technology by large and medium enterprises in China's Statistical Yearbook.

S\&T stock in 1998 was calculated as five times the flow in that year. S\&T stock in subsequent years is calculated by adding the flow in year $t$ to the stock in year $t-1$, discounted at $15 \%$.

Because we were unable to exclude the possibility of a unit root in value added, all models are estimated in first difference form S\&T Spillover is the sum of S\&T stocks from all other industries.

Values in parentheses are p-values calculated using robust standard errors

Significance levels $* * *, * *$, and $*$ are $\mathrm{p}<0.01,0.05$, and 0.1 , respectively

Weighted S\&T Spillover weights S\&T stocks from all other industries using input-output coefficients

Estimates reported above represent semi-elasticities 


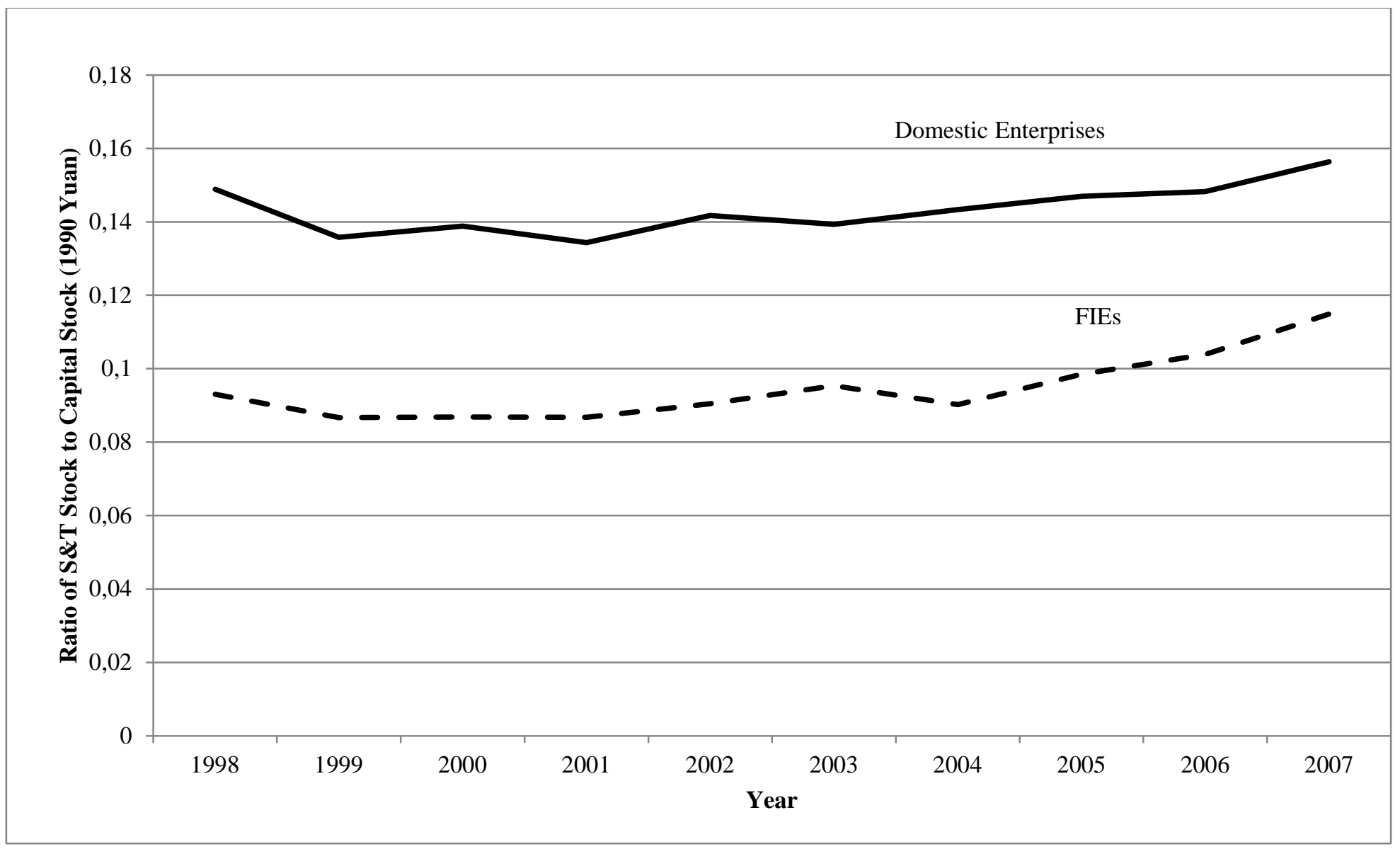

